
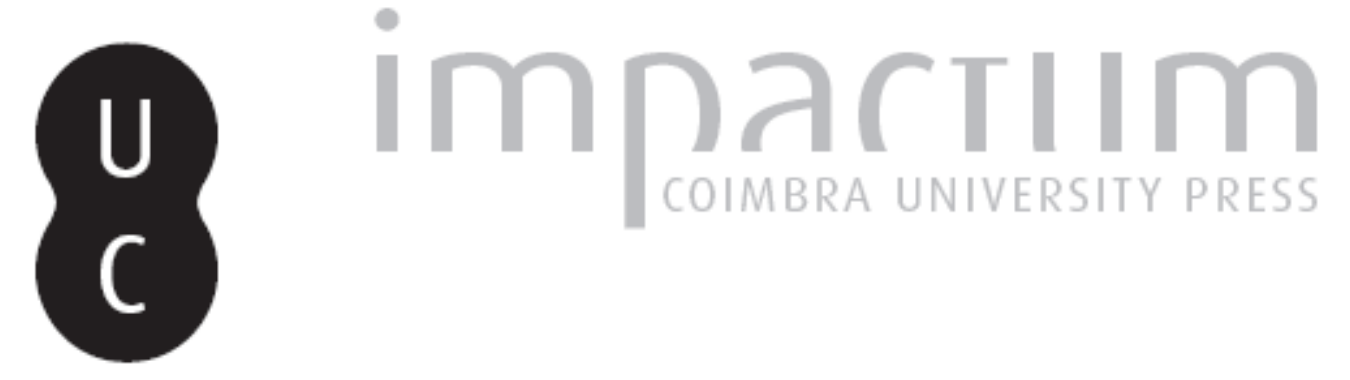

\title{
"That Squalid Nest of peasants in the Genovese Country": clichés and heterostereotypes in Henry Jaimes's italian tales
}

Autor(es): $\quad$ Llitnlr, Arnold G.

Publicado por: Faculdade de Letras da Universidade de Coimbra

URL persistente:

URI:http://hdl.handle.net/10316.2/38982

DOI:

DOI:http://dx.doi.org/10.14195/0870-4112_1_7

Accessed : $\quad$ 26-Apr-2023 10:21:53

A navegação consulta e descarregamento dos títulos inseridos nas Bibliotecas Digitais UC Digitalis, UC Pombalina e UC Impactum, pressupõem a aceitação plena e sem reservas dos Termos e Condições de Uso destas Bibliotecas Digitais, disponíveis em https://digitalis.uc.pt/pt-pt/termos.

Conforme exposto nos referidos Termos e Condições de Uso, o descarregamento de títulos de acesso restrito requer uma licença válida de autorização devendo o utilizador aceder ao(s) documento(s) a partir de um endereço de IP da instituição detentora da supramencionada licença.

Ao utilizador é apenas permitido o descarregamento para uso pessoal, pelo que o emprego do(s) título(s) descarregado(s) para outro fim, designadamente comercial, carece de autorização do respetivo autor ou editor da obra.

Na medida em que todas as obras da UC Digitalis se encontram protegidas pelo Código do Direito de Autor e Direitos Conexos e demais legislação aplicável, toda a cópia, parcial ou total, deste documento, nos casos em que é legalmente admitida, deverá conter ou fazer-se acompanhar por este aviso.

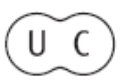




\section{Culturas em Diálogo}

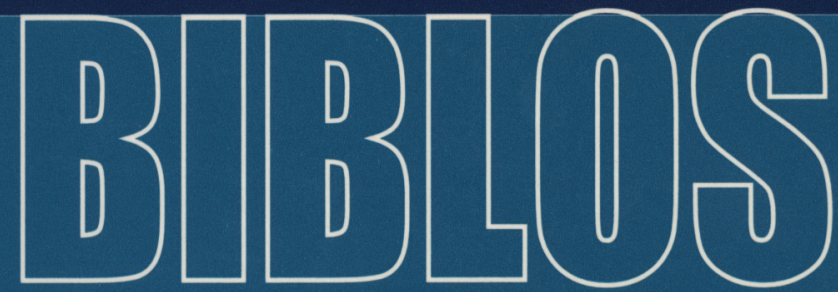




\section{"That Squalid Nest of peasants in the Genovese Count ry": Cl ichés and Het erostereotypes in Henry Jaimes's It al ian Tal es ${ }^{1}$}

Henry James is generally considered to be a lover of Italy, and this not without good reason. His travel sketches and his letters home from Italy effervesce with enthusiasm for Venice, the city of his lifelong devotion, for the galleries of Florence and the churches of Rome. When James for the first time set foot in the Eternal City in 1869 he was overwhelmed with a feeling of awe and wonder. In a letter to his brother William he was but barely able to put his excitement into words:

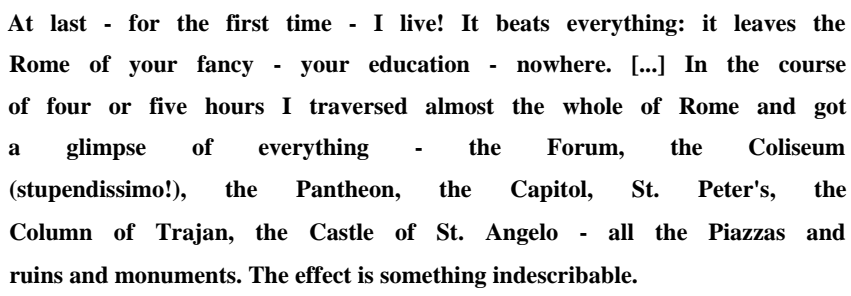

\{Letters, I, 24)

After this first visit in 1869 James returned to Italy almost on a regular basis. In the 1870 s and 1880 s more than a dozen trips to Italy some indeed were prolonged to month-long sojourns in Rome or Florence - nourished James's affections for Italy and kindled his enthusiasm for Italian art. Therefore it does not come as a surprise that James, after a lifetime of travelling all over Europe, was prepared to eulogise the country as the most beautiful in the world: "Italy is the most beautiful country in the world - of a beauty (and an interest and complexity of beauty) so far beyond any other that none other is worth talking about" \{Letters, II, 80).

1 Research for this paper was made possible in part by the Austrian Academy of Sciences, who awarded me a grant to complete my dissertation on Henry James. 
Much has been written on James's affection for Italy: Robert L. Gale, for one, was the first to comment extensively on James's relationship with Italy, and Sergio Perosa, as another example in point, has closely analysed James's devotion to Northern Italy and Venice. Although it remains undisputed that James paid his homage to Italy in his travel writings, I would not agree unreservedly that James did likewise in his tales and novels. Neither do I agree with the aforementioned Robert Gale, who claims that there are "no Italian villains in James's fiction" (1959:164). In the following pages I will focus on a few of the approximately twenty tales by James which are cast entirely or partly in Italy or include Italian characters, pointing out those instances in James's writings which reveal a more complex and more controversial approach to Italy.

James's first tale to deal extensively with Italy is "Travelling Companions". It was written in 1870, when James was back in Cambridge, trying to digest the impressions of his wanderjahr in Europe, which had led him to England, France and for the first time also to Italy. The synopsis of "Travelling Companions" can be rendered in a few words: Mr Brooke, a young American travelling Italy from Milan to Naples, woos his compatriot Miss Evans, who tours the peninsula together with her father. Mr Brooke's first overtures to his travelling companion are not discouraged, his subsequent proposal of marriage to Miss Evans, however, is turned down. When Miss Evans' father suffers an apoplectic stroke and dies shortly afterwards, she accepts Mr Brooke's renewed proposal. The last item on the agenda of their sightseeing tour, Florence, they visit already as husband and wife.

Considering the apparent flatness of the plot, it is not surprising that "Travelling Companions" is one of the approximately thirty tales by Henry James which were singled out by the Master himself and not taken into consideration as not eligible for publication in the definite, monumental edition of his tales and novels, the so-called New York Edition. "Travelling Companions", however, is outstanding as a celebration of Italian art, of Italian paintings, buildings, cities and scenery. In fact, the opening sentence of "Travelling Companions" is symptomatic of the predominant theme of the entire tale: "The most strictly impressive picture in Italy is incontestably the Last Supper of Leonardo at Milan" (171). Apart from Leonardo, Mr Brooke and Miss Evans are thrilled by Giotto, are moved to tears by Tintoretto's Crucifixion and spend hours of delight admiring Paul Veronese's frescoes in the Ducal Palace of Venice. They rave about the Italian scenery, spend 
their evenings in little piazzas drinking in the Mediterranean atmosphere and express their enthusiasm in interjections charged with emotion: "Ah! This is Italy!" (180), they exclaim, or "It's the South, the South [...] the South in nature, in man, in manners. [...] It's the South, [...] don't you feel it in all your nerves?" (181)

In spite of all the professed enthusiasm for Italy which without doubt carries also autobiographical traits, "Travelling Companions" cannot be pronounced as unanimously well disposed towards Italy. The reader of the tale will notice that contact between the two American protagonists and the local Italians is virtually non-existing or is limited to a few words to their gondoliere or the sacristan who ushers them into the various churches. It seems as if their interest in Italy stops short of the Italian. In the whole tale only one encounter worth mentioning between Mr Brooke and a young Italian takes place: Mr Brooke who travels from Milan to Venice visiting some smaller Italian cities on his way, is approached by a young Italian in Vicenza. After a short introductory conversation the young man claims to be in possession of a "most divine little Correggio" (187) which his financial plight forces him to give away for an exceptionally good price. Although $\mathrm{Mr}$ Brooke is somewhat suspicious about the picture's authenticity, he agrees to have a look at it. At the Italian's lodgings the expert's eye discerns at once that the simple composition of a Madonna and child, the pretended Correggio, is a forgery. When he expresses his doubts about the quality of the picture, he is confronted with the allegedly critically ill sister of the young man who recounts her last night's dream of a gentleman who bought the picture of the Madonna for a large sum of money. Unable not to live up to the dying girl's expectations $\mathrm{Mr}$ Brooke finally purchases the picture. Not surprisingly, the impression of the Italians conveyed to the readers is not a favourable one. This begins with the description of the outward appearance of the young Italian male. Although his features are described as delicate, his dress and outward appearance are shabby. His lodgings are equally poor and they are flooded with the inevitable odour of onions. The verdict on those Italians' character is - in view of their dishonest intentions - as unpleasant as expected. The visit to the little Vicenza household fills Mr Brooke with "a painful, indefinable sadness" (191), which originates in the low moral standards he had to ascertain in the Italian family: "So beautiful they all were, so civil, so charming, and yet so mendacious and miserable!" (191) Given the fact that it is the one and only opinion on Italians pronounced in the entire tale, mendacity as their 
dominant character trait feature carries a lot of weight and throws a very negative light on Italians in general.

Mr Brooke and Miss Evans may be depicted as enthusiasts for Italian art and as tireless visitors of churches and museums from Milan to Naples, their interest in the Italian people, in the Italian per se, however, is shallow. The only intercultural encounter shown in the tale takes an unpleasant turn and the Italians, depicted as mendacious and deceitful, are denigrated and shown in a bad light.

This is not an exception or an isolated case limited only to James's first Italian tale as some recurring clichés and heterostereotypes concerning the Italians in James's tales will reveal.

One of the character traits recurrently attributed to the Italians depicted in James's tales is avarice. Considering those tales which deal with intercultural and transatlantic liaisons, engagements and marriages, the Italians' quest for pecuniary benefits is remarkably highlighted. In "The Last of the Valerii" Count Valerio's estate - a villa within the walls of Rome - suffers from his chronic lack of money and is, as the narrator of the tale euphemistically remarks, in a state of "disrepair" (91). Structural improvements of the villa can only be financed with his American wife's money. The narrator of the tale is quite explicit in his judgement on the Count's interest in his wife's fortune: He maintains that Conte Valerio, "like a good Italian" (99), has taken exact measure of his fiancée's money before letting himself be caught by her looks and her personal charms. The narrator's remark that it behoves every "good Italian" to inquire into the financial situation of his promessa sposa before committing himself is revealing - not so much as the Italian national character is concerned, but more so concerning the vantage point from which the Italians are looked at in James's tales.

In the late tale "Miss Gunton of Poughkeepsie" (written in 1900) the pecuniary interest of an Italian in an American lady's money is made even more explicit. Judging from the large amount of money she freely disposes of, Lily Gunton, a young American travelling Europe, must be handsomely rich. Rich enough at least for a Roman prince to be interested in her and to follow her from Rome to Florence, to Paris and eventually to London. In the entire tale the reader doesn't get a single plausible explanation for the attraction of a member of the Italian aristocracy to a charming, but otherwise altogether common girl: The nameless prince is enchanted by her money. When Lily Gunton, whose only communication with her family in Poughkeepsie is on the subject of drawing money, draws and spends money at a vertiginous rate, the Italian 
prince feels compelled to ask for her hand lest the capital at her disposal should dwindle away completely. The narrative is quite explicit about the prince's motives: "He desired to rescue the remainder" of Miss Gunton's fortune (82). Although later in the tale the prince claims to be in love with Lily, it is quite obvious that her financial situation adds a considerable part to her attractiveness. When Lily finally breaks off the engagement because of cultural misunderstandings, the Italian prince is stricken with regret - for the loss of American dollars, that is.

The two tales mentioned provided only a few examples of a larger number of Italians depicted as avaricious and decried as fortunehunters. (Another example is Mr Giovanelli in James's well known tale "Daisy Miller" who is said to be one of the "regular Roman fortunehunters" (172) intent on marrying money.) As far as international marriages are concerned, the scenario shown in James's Italian tales is that of an impoverished Italian lying in wait for a prosperous New England girl, his gallant efforts increasing in proportion to the young woman's fortune.

The Italian fortune-hunter is only one side of a character study with manifold aspects. Reading James's fiction it also becomes conspicuous that a number of the Italian characters in his tales are portrayed as somewhat simple-minded, or, to say it bluntly, as stupid.

Let us briefly consider "Adina", another of James's tales cast in Rome. In "Adina" the American Sam Scrope cheats an Italian peasant who has dug up a beautiful topaz without recognising its enormous value. When the Italian Angelo Beati realises that he has sold the gem for a fraction of its worth, Scrope refuses to make a restitution. Angelo's revenge is not violent, but still terrible for Scrope. The Italian woos Scrope's fiancée, Adina, elopes with her and is secretly married to her in a small church in the Albano hills. Since the reader cannot but feel that Scrope is well served, it is the more surprising that the Italian is still portrayed as slow-witted, shabby in his outward appearance and coarse in his behaviour. When the narrator of the tale first meets Angelo, he calls him a "clodhopper" (214), a derogatory term which marks the narrator's sense of superiority with respect to his Italian interlocutor. This particular stance of superiority is perceptible especially at the beginning of the tale. We can read that the narrator wonders whether Angelo is "under-witted" (211), later he is called a "giggling lout" (217), his smile is "strange" (222) and his nature is "indolent" (233).

This description of the slow-witted Italian is matched by the impression the reader gets of the main Italian character in the 
aforementioned tale "The Last of the Valerii". There Count Valerio is described as rather dull: Political or aesthetic questions are asked to no avail and his topics of conversation are limited to such an extent as to make the narrator of the tale remark that Valerio is as entertaining when he is asleep as when awake. As reading the newspaper already makes Valerio fall asleep, the narrator doubts that Valerio will ever turn a page of Dante's Divina Commedia. Valerio is actually described as similar to an animal, his behaviour being purely instinctive and not controlled by reflection or finer spiritual emotions: Valerio has "no beliefs nor hopes nor fears", he is "nothing but senses, appetites and [...] luxurious tastes" (95). The opposition between instinct and physical desires on the one hand, intellect and reason on the other, in other words the classical distinction between ratio and emotio, is applied to the Italians in James's tales. The sensuousness of the Italians apparently excludes them from logical reasoning.

The emphasis on instinctive behaviour in James's Italian tales is connected with another feature attributed to the Italian character violence. In "Adina" Angelo Beati employs his masculine looks to steal Sam Scrope's fiancée and thus takes his revenge without resorting to violence. The non-violent Italian, however, is rather the exception, not the rule, in James's tales: In the early tale "At Isella" an American meets a beautiful Italian woman who apparently is in great distress. After a while she takes her fellow-traveller into her confidence and confesses that she is fleeing from her brutal husband. In her narrative the reader gets to know that her Italian husband beat her, starved her and used to lock her up without light or fire. These acts of violence committed by an Italian are the more significant as nowhere else in James's other hundred and more tales a similar behaviour is attributed to a member of any other nationality, be it French, German or English.

The willingness to resort to violent actions is also reflected in another, until now not mentioned tale by James. In "The Diary of a Man of Fifty" the reader learns that a jealous Italian husband strikes his supposed rival - also an Italian - in the face. This makes the violence escalate and the matter has to be resolved in a duel. The duel is fought with swords and the offended husband receives a fatal wound. The victor, however, can't brag about his triumph for very long: He is killed in another duel some years afterwards. The high number of duels fought by Italians in James's tales is directly linked to another seemingly characteristic Italian feature - adultery. The beautiful Italian lady on the run in "At Isella" is not only fleeing from her brutal husband, she is also 
on her way to her lover in Switzerland. And the fatal duels fought in "The Diary" are the result of an alleged romantic attachment of an Italian to a married Italian Countess.

As if the picture of the Italian as painted in some of James's tales weren't already grim enough, let us - to round off the list of Italian misdemeanour - consider one more tale which hasn't been contemplated until now. The tale in question is the lesser known narrative "Georgina's Reasons". In it Georgina Gressie secretly and in disobedience of her parents' wishes marries the naval officer Raymond Benyon, who has to swear never to claim her without her concurrence. When Georgina becomes pregnant, she embarks on a trip to Europe accompanied only by a lady-friend. In Italy she gives birth to a healthy child, leaves it with an Italian nurse and returns to New York where she marries again. Only much later does Benyon learn that his wife leads the life of a bigamist. He demands that she permit him to divorce her so that he may legally marry the woman he is attached to. But Georgina refuses to release him from his vow and Benyon sacrifices his own happiness for the woman who has deserted him and committed bigamy besides.

This weird and sensational story which (for a Jamesian tale) exerts an atypical fascination is enriched by another somewhat sinister detail, which concerns the fate of Georgina's little baby left in the custody of an Italian nurse. When Benyon, the baby's father, learns of the existence of his son, he immediately betakes himself to Italy in order to look for his child and to assume possession of it. His attempts to claim back his child in "that squalid nest of peasants in the Genoese country" (71), however, remain futile. What he encounters in the Genoese hills is described in the most vivid terms of which "squalor" is a comparatively harmless expression used in this tale. Benyon is confronted with "confessions, retractions, contradictions, lies, terrors, threats, and general bottomless, baffling mendacity and idiocy of every one in the place" (71). To cut a long story short, Benyon's son has disappeared and the various accounts given of his fate range from his premature death to being kidnapped by a distant relative of the nurse. The reason behind the dozen different stories concerning the baby's fate is given without much ado: The version that the child has died is maintained by the inhabitants "in the hope of being rewarded for [their] candour", the story that he is still alive "in the hope of being remunerated for [their] good news" (72). In "Georgina's Reasons" we find, as it were, a conglomeration of all the negative character traits ascribed to the Italians in James's other tales. From avarice to mendacity, from idiocy to deceitfulness, everything can 
be encountered in "Georgina's Reasons". Between the lines we can even gather that the child's father harbours a suspicion which he doesn't dare to put into words: murder, or rather infanticide, as another possibility to explain the little baby's disappearance.

Let us briefly recapitulate: Although James expresses his love and devotion to Italy in his letters and travel writings, he does not do so in his tales. In the brief survey of a few of his tales it has become evident that the Italians as depicted by James leave an altogether unfavourable impression: They are shown as vulgar, deceitful, avaricious, slow-witted, lecherous, violent, adulterous, and sometimes also obscene. Although obviously not every Italian is a villain, the Italian hero in James's tales is virtually non existing.

The question that imposes itself is certainly how to reconcile the grim picture of Italy as painted in James's tales on the one hand and his enthusiasm for Italy voiced in countless letters and travelogues on the other. Or, to put it another way, why does James, a professed lover of Italy, present the readers of his fiction with such a negative picture of the native Italian?

Answers to this seeming paradox may lie both in imagological stereotypes expounded in literary sources and derived from there by James as well as in James's own personal experiences made in Italy. Umberto Mariani has pointed out in his essay "The Italian Experience of Henry James" that James's earliest sense of Italy was determined by romantic Tuscan landscape paintings and strengthened by his reading Byron, Shelley and Hawthorne, just to name a few of his literary guides (1964:238). This romantic conception of Italy may account for James's enthusiasm for Italy in his letters and travel, but it can't explain satisfactorily the dark picture of Italy which James paints in his tales. In order to find an adequate explanation for the low regard for the Italians in James's tales we have to go further back in literary history.

As Franz K. Stanzel expounds in his recently published study on the making of national character Europàischer Volkerspiegel, the most favourable ground for opinions about foreigners to become long-lasting stereotypes is when they enter literature (1999:12). Not only do they grow and flourish there, literary tradition also supplies a richly stocked arsenal of national stereotypes to other authors and playwrights. In the $17^{\text {th }}$ century dictionaries of poetical words and phrases even listed adjectives which were thought to be appropriate for the description of the national characters of the various nationalities such as Spaniards, Frenchmen and Germans. There the Italians are recurrently described as deceitful, violent 
and vindictive. At the beginning of the $18^{\text {th }}$ century an Austrian (whose name has been forgotten), evidently well acquainted with stereotyped national characteristics, listed the supposedly outstanding features of the main European nations in a systematic way on the so-called "Volkertafel".2 F. K. Stanzel who has, as it were, unearthed the "Volkertafel" and thus preserved it from oblivion, shows that its author resorted in his descriptions to ideas about national character "dominant in European thought in the late seventeenth and early eighteenth centuries" (1995:4). Judging from the description of the Italian, the prevalent attitude towards Italy must have been very negative: Among other things the Italian is said to be underhanded, deceitful, jealous, lecherous and avaricious.

In 1785 a travelogue by the Prussian officer Johann Wilhelm von Archenholtz gave new impetus to the pejorative opinion on Italy and its inhabitants. Although Archenholtz has nowadays almost completely fallen into oblivion, his travelogue received so much attention that it was reprinted several times, was translated into French, English, Dutch, Swedish and even Russian, and, by way of financial success, enabled Archenholtz to marry and start a family (cf. Maurer 1987:185). The book's influence on the English-speaking world was not only due to the English translation, but also because of its title, England und It alien, and the detailed comparisons between these two countries. There England is described as the epitome of reason and knowledge, of industry, commerce and advanced technologies, of unity and an efficient form of government. Italy, on the other hand, is associated with political chaos, ignorance, violence, poverty and immorality (cf. Battafarano 1997:43, Archenholtz 1787:132, 140). Archenholtz's study not only conveys his own personal opinion, but repeats prevalent ideas and stereotypes of $18^{\text {th }}$ century Italy falling back among others on Tobias Smollett, Samuel Sharp, Joseph Addison and Thomas Burnett (cf. Battafarano 1997:41). The heterostereotypes conveyed by the aforementioned authors and by Archenholtz are consistent with the portrayal of the Italian on the "Volkertafel" and give a uniformly pejorative image of Italy.

Fleterostereotypes like the ones mentioned above were not confined to Europe, but were also exported to the New World where the American settlers were slow in abandoning inherited clichés (cf. Zacharasiewicz 1982:98). Stanzel points out that the early American

\footnotetext{
${ }^{2}$ For further information on the "Volkertafel" 1 refer the reader to F. K. Stanzefs aforementioned book.
} 
writer George Alsop, for example, compared the shameless behaviour of Indian women to the obscenity of women in Italy, in particular those of Venice (1995:7). During the War of Independence and the subsequent processes of national emancipation from Europe stereotypes were again foregrounded and also found their way into colonial and early American literature. As Waldemar Zacharasiewicz has shown, American authors and playwrights drew extensively on classical clichés in the description of foreign figures (1982:101). The close correspondence between these classical heterostereotypes and the picture of the Italian as painted by James in his tales could be an indication that James, visiting the Old World, brought with him memories of the traditional national characteristics of Europeans. Thus when James descended from the Simplon to Italy for the first time, it wasn't only an exposure to the Italy of factuality, but also a progress through the Italy of his forefathers.

When the 26-year-old James visited Italy for the first time, the dominant characteristic of his first contact with Italy were his stereotyped distortions - Italy as a country of artistic wealth but economic poverty, a country of great beauties but also great dangers, a country for which the Coliseum in its majestic beauty and pitiful decay seemed to be deeply symbolic. But while time and the frequent visits to Italy toned down the exaggerations of his art criticism and his somewhat histrionic exclamations, his stereotyped notions of the native Italian remained. One reason might be that James never really came close to comprehending the Italian people. James never mastered the Italian language to a satisfactory extent and probably as a result never became familiar with native Italians. James himself complained in one of his letters from Italy that his acquaintances were mainly "waiters and washerwomen". He remained an outsider for years and felt uneasy as he was only scraping the surface of things. Who could express this feeling better than James himself, saying of Venice: "Venice is quite the Venice of one's dreams, but it remains strangely the Venice of dreams, more than of any appreciable reality "\{Letters I, 134). Despite his position as an outsider James did not hesitate to give his opinion on questions requiring thorough insight such as the Italian moral standards or their degree of civilisation. On these occasions James seems to have fallen back mostly on his storehouse of clichés which provided him with a variety of national stereotypes. What else but traditional clichés could have induced the same James who just complained about Venice remaining unreal to him to claim that the Venetians lie, that they "steer a crooked course" and love "if not too well at least too often"? (Italian Hours 16). One more example of James's 
biased judgement of the Italian character - distorted by a common prejudice - should be mentioned: In his Italian Hours James gives an account of two evenings he spent in the theatre in Rome. In the Teatro Valle James went to see a comedy by Carlo Goldoni in Venetian dialect. Although James has to admit that he could understand only half of the play he doesn't hesitate to compare it to its great disadvantage with a performance of Molière's Malade Imaginaire he had seen in Paris a year before. In James's opinion the Italian play is less intellectual and less subtle in its humour, the acting is described as easy, free and natural, but wanting in finesse. His feelings in an Italian performance of Othello a few days later stem from the same cliché. The Italian acting is described as very bad and very fine at the same time - excellent when "violent passion" is at stake, poor when anything like taste and discretion is required. James verbatim:

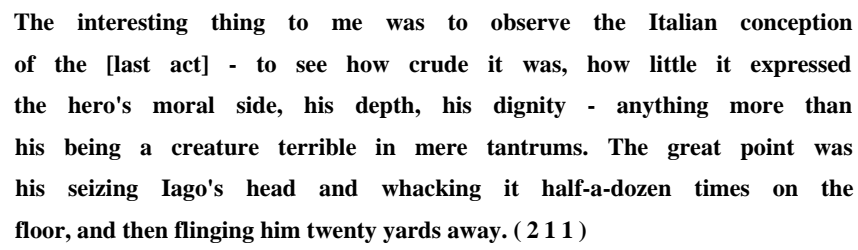

"The innocent eye is a myth", the art historian E. H. Gombrich stated a quarter of a century ago, and we can assume that national stereotypes and clichés not only determined the depiction of the Italian in James's tales, but also influenced his way of experiencing Italy. In that respect he is similar to one of the characters in his tale "Four Meetings" who claims to know Italy because she has read Byron. A quotation from that specific tale sums up our main argument. With it we may close: "The native American passion [for foreign countries] is primordial - antecedent to experience. Experience comes and only shows us something we have dreamt of' (92).

\section{WORKS CITED}

- Archenholtz, Johann W., England und Italien. Karlsruhe: Christian Gottlieb Schmieder, 1787.

- Battafarano, Italo M., "Der Weimarer Italienmythos und seine Negation: Traum-Verweigerung bei Archenholtz und Nicolai." Manger 39-78. 
- Gale, Robert., "Henry James and Italy." I9,h Century Fiction 14 (1959): 157-170.

- James, Henry, "Adina." The Complete Tales of Henry James III, 211257.

- Id./'Daisy Miller: A Study." The Complete Tales of Henry James IV, 141-207.

- Id., "Four Meetings." The Complete Tales of Henry James IV, 87-1 18.

- Id., Italian Hours. New York: Grove Press, 1959.

- Id., "Miss Gunton of Poughkeepsie." The Complete Tales of Henry James IX, 77-92.

- Id., The Complete Tales of Henry James. Ed. Leon Edel. 12 vols. London: Rupert Hart-Davis, 1963.

- Id., "The Diary of a Man of Fifty." The Complete Tales of Henry James IV, 389-425.

- Id., "The Last of the Valerii." The Complete Tales of Henry James III, 89-122.

- Id., "Travelling Companions." The Complete Tales of Henry James II, 171-225.

- Lubbock, Percy, ed., The Letters of Henry James. New York: Charles Scribner's Sons, 1920.

- Manger, Klaus, ed., Italienbeziehungen des klassischen Weimar. Tiibingen: Niemeyer, 1997.

- Mariani, Umberto, "The Italian Experience of Henry James." $J 9^{\prime h}$ Century Fiction 19 (1964): 237-254.

- Maurer, Michael, Aufklärung und Anglophilie in Deutschland. Göttingen, Zurich: Vandenhoeck und Ruprecht, 1987.

- Perosa, Sergio, "Henry James and Northern Italy." Zacharasiewicz 119127.

- Stanze 1, Franz K. (ed.), Europäischer Völkerspiegel. Imagologisch ethnographische Studien zu den Völkertafeln des frühen 18. Jahrhunderts. Heidelberg: Winter, 1999.

- Id., "National Stereotypes in Literature." Zacharasiewicz 1-9.

- Zacharasiewicz, Waldemar, ed., Images of Central Europe in Travelogues and Fiction by North American Writers. Tübingen: Stauffenburg, 1995.

- Id., "National Stereotypes in Literature in the English Language: A Review of Research." REAL 1 (1982): 75-120. 